\title{
The Rights of Animals: A Very Short Primer
}

\section{Citation}

Cass R. Sunstein, The Rights of Animals: A Very Short Primer (Public Law \& Legal Theory Working Papers No. 30, 2002).

\section{Published Version}

http://chicagounbound.uchicago.edu/public_law_and_legal_theory/340/

\section{Permanent link}

http://nrs.harvard.edu/urn-3:HUL.InstRepos:12795545

\section{Terms of Use}

This article was downloaded from Harvard University's DASH repository, and is made available under the terms and conditions applicable to Other Posted Material, as set forth at http:// nrs.harvard.edu/urn-3:HUL.InstRepos:dash.current.terms-of-use\#LAA

\section{Share Your Story}

The Harvard community has made this article openly available.

Please share how this access benefits you. Submit a story.

\section{Accessibility}




\section{University of Chicago Law School Chicago Unbound}

Public Law and Legal Theory Working Papers

Working Papers

2002

\section{The Rights of Animals: A Very Short Primer}

Cass R. Sunstein

Follow this and additional works at: http://chicagounbound.uchicago.edu/ public_law_and_legal_theory

Part of the Law Commons

\section{Recommended Citation}

Cass R. Sunstein, "The Rights of Animals: A Very Short Primer" (Public Law \& Legal Theory Working Papers No. 30, 2002).

This Working Paper is brought to you for free and open access by the Working Papers at Chicago Unbound. It has been accepted for inclusion in Public Law and Legal Theory Working Papers by an authorized administrator of Chicago Unbound. For more information, please contact unbound@law.uchicago.edu. 


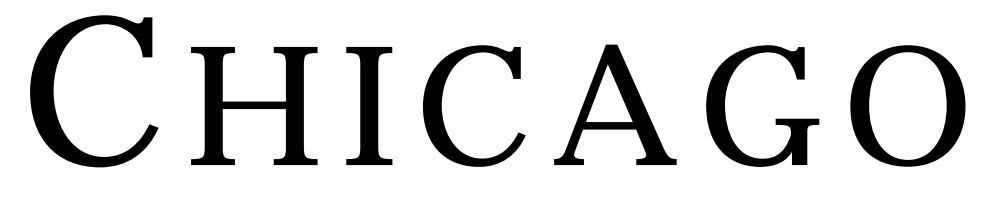

Public Law And legal Theory Working Paper No. 30

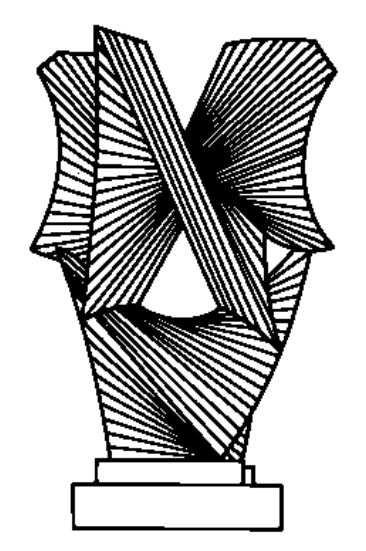

\title{
The Rights of Animals: A Very Short Primer
}

\author{
Cass R. Sunstein \\ THE LAW SCHOOL \\ THE UNIVERSITY OF CHICAGO
}

This paper can be downloaded without charge at the Public Law and Legal Theory Working Paper Series: http://www.law.uchicago.edu/academics/publiclaw/index.html

The Social Science Research Network Electronic Paper Collection:

http://ssrn.com/abstract_id=323661 


\title{
The Rights of Animals: A Very Short Primer
}

\author{
Cass R. Sunstein
}

\begin{abstract}
Do animals have rights? Almost everyone believes in animal rights, at least in some minimal sense; the real question is what that phrase actually means. By exploring that question, it is possible to give a clear sense of the lay of the land-to show the range of possible positions, and to explore what issues, of theory or fact, separate reasonable people. On reflection, the spotlight should be placed squarely on the issue of suffering and well-being. This position requires rejection of some of the most radical claims by animal rights advocates, especially those that stress the "autonomy" of animals, or that object to any human control and use of animals. But this position has radical implications of its own. It strongly suggests, for example, that there should be extensive regulation of the use of animals in entertainment, in scientific experiments, and in agriculture. It also suggests that there is a strong argument, in principle, for bans on many current uses of animals.
\end{abstract}

\section{Dogs, Cats, and Principle}

There are nearly sixty million domestic dogs in the United States, owned by over thirty-six million households. Over half of these households give Christmas presents to their dogs. Millions of them celebrate their dog's birthday. If a family's dog were somehow forced to live a short and painful life, the family would undoubtedly feel some combination of rage and grief. What can be said about dog owners can also be said about cat owners, who are more numerous still. But through their daily behavior, people who love those pets, and greatly care about their welfare, help ensure short and painful lives for millions, even billions of animals that cannot easily be distinguished from dogs and cats. Should people change their behavior? Should the law promote animal welfare? Should animals have legal rights? To answer these questions, we need to step back a bit.

Many people think that the very idea of animal rights is implausible. Suggesting that animals are neither rational nor self-aware, Immanuel Kant thought of animals as "man's instruments," deserving protection only to help human beings in their relation to one another: "He who is cruel to animals becomes hard also in his dealings with men."1 Jeremy Bentham took a different approach, suggesting that mistreatment of animals was akin to slavery and racial discrimination. "The day may come when the rest of the animal creation may acquire those rights which never could have been withholden from them but

\footnotetext{
* Karl N. Llewellyn Distinguished Service Professor of Jurisprudence, Law School and Department of Political Science, University of Chicago. I am grateful to Emily Buss, Gary Francione, Martha Nussbaum, Richard Posner, Janet Radcliffe Richards, and David Wolfson for valuable comments on a previous draft. Alexandra Baj provided valuable research assistance.

${ }^{1}$ Immanuel Kant, Lectures on Ethics, trans. Louis Infield (New York: Harper Torchbooks, 1963), at 240.
} 
by the hand of tyranny. The French have already discovered that the blackness of the skin is no reason why a human being should be abandoned without redress to the caprice of a tormentor. . . . A full-grown horse or dog is beyond comparison a more rational, as well as a more conversable animal, than an infant of a day, or a week, or even month, old. But suppose the case were otherwise, what would it avail? the question is not, Can they reason? Nor, Can they talk? But, Can they suffer?"2 John Stuart Mill concurred, repeating the analogy to slavery. ${ }^{3}$

Most people reject that analogy. But in the last ten years, the animal rights question has move from the periphery and toward the center of political and legal debate. The debate is international. In 2002, Germany became the first European nation to vote to guarantee animal rights in its constitution, adding the words "and animals" to a clause that obliges the state to respect and protect the dignity of human beings. ${ }^{4}$ The European Union has done a great deal to reduce animal suffering. ${ }^{5}$ Within the United States, consumer pressures have been leading to improved conditions for animals used as food. ${ }^{6}$ Notwithstanding its growing appeal, the idea of animal rights has been disputed with extraordinary intensity. Some advocates of animal rights think that their adversaries are selfish, unthinking, cruel, even morally blind. Some of those who oppose animal rights think that the advocates are fanatical and even bizarre, willing to trample on important human interests for the sake of rats and mice and salmon.

In this essay I have three goals. The first is to reduce the intensity of the debate by demonstrating that almost everyone believes in animal rights, at least in some minimal sense; the real question is what that phrase actually means. My second goal is to give a clear sense of the lay of the land-to show the range of possible positions, and to explore what issues separate reasonable people. In this way, I attempt to provide a kind of primer for current and coming debates. The third goal is to defend a particular position about animal rights, one that, like Bentham's, puts the spotlight squarely on the issues of suffering and well-being. ${ }^{7}$ This position requires rejection of some of the most radical claims by animal rights advocates, especially those that stress the "autonomy" of animals, or that object to any human control and use of animals. But my position has radical implications of its own. It strongly suggests, for example, that there should be extensive regulation of the use of animals in entertainment, scientific experiments, and agriculture. It also suggests that there is a strong argument, in principle, for bans on many current

\footnotetext{
${ }^{2}$ See Jeremy Bentham, The Principles of Morals and Legislation, chap. XVII, section IV [1781] (Amherst, NY: Prometheus Books, 1988), at 310-11.

3 See John Stuart Mill, Whewell on Moral Philosophy, in John Stuart Mill \& Jeremy Bentham, Utilitarianism and Other Essays 228, 252 (Alan Ryan ed., 1987).

${ }^{4}$ John Hooper, German parliament votes to give animals constitutional rights, The Guardian (London) May 18, 2002, the Guardian Home Pages, Pg. 2.

${ }^{5}$ See note infra.

${ }^{6}$ Chicago Tribune, June 26, 2002, p. 9, John Keilman, Food retailers press for humane farming; Industry, animal activists reaching some suppliers.

${ }^{7}$ By putting the spotlight there, I do not mean to resolve a hard question: Whether an animal that is subject to a life of deprivation, and that entirely adapts to that life, is nonetheless being treated in a way that violates its rights. In brief, I believe that like a human being, an animal that adapts to deprivation has a reasonable ground for complaint, if the deprivation means that its life is much worse than it might be. But I cannot discuss that issue here.
} 
uses of animals. In my view, those uses might well be seen, one hundred years hence, to be a form of unconscionable barbarity. In this respect, I suggest that Bentham and Mill were not wrong to offer an analogy between current uses of animals and human slavery.

\section{What Animal Rights Might Entail}

\section{A. The Status Quo}

If we understand "rights" to be legal protection against harm, then many animals already do have rights, and the idea of animal rights is not at all controversial. And if we take "rights" to mean a moral claim to such protection, there is general agreement that animals have rights of certain kinds. Of course some people, including Descartes, have argued that animals are like robots and lack emotions -- and that people should be allowed to treat them however they choose. ${ }^{8}$ But to most people, including sharp critics of the animal rights movement, this position seems unacceptable. Almost everyone agrees that people should not be able to torture animals or to engage in acts of cruelty against them. And indeed, state law contains a wide range of protections against cruelty and neglect. We can build on existing law to define a simple, minimal position in favor of animal rights: The law should prevent acts of cruelty to animals.

In the United States, state anticruelty laws go well beyond prohibiting beating, injuring, and the like, and impose affirmative duties on people with animals in their care. New York contains a representative set of provisions. Criminal penalties are imposed on anyone who transports an animal in a cruel or inhuman manner, or in such a way as to subject it to torture or suffering, conditions that can come about through neglect. ${ }^{9}$ People who transport an animal on railroads or cars are required to allow the animal out for rest, feeding, and water every five hours. ${ }^{10}$ Nonowners who have impounded or confined an animal are obliged to provide good air, water, shelter, and food. ${ }^{11}$ Those who abandon an animal in public places, including a pet, face criminal penalties. ${ }^{12}$ A separate provision forbids people from torturing, beating, maiming, or killing any animal, and also requires people to provide adequate food and drink. ${ }^{13}$ Indeed it is generally a crime not to provide necessary sustenance, food, water, shelter, and protection from severe weather. ${ }^{14} \mathrm{New}$ York, like most states, forbids overworking an animal, or using the animal for work when she or he is not physically fit. ${ }^{15}$ Compare in this regard the unusually protective California statute, which imposes criminal liability on negligent as well as intentional overworking, overdriving, or torturing of animals. "Torture" is defined not in its

\footnotetext{
${ }^{8}$ See Gary B. Francione, Introduction to Animal Rights 2, 73 (2000).

${ }^{9}$ NY Agri \& Mkt. 359.

${ }^{10}$ NY Agri \& Mkts 359.

${ }^{11}$ NY Agri \& Mkts 356.

${ }^{12}$ NY Agri \& Mkts 355.

${ }^{13}$ NY Agri \& Mkts 353.

${ }^{14}$ See Griffth v. State, 43 SE 251 (1903); Commonwealth v. Lufkin, 7 Allen 579; State v. Groseclose, 171 P2d 863 (1946); Reynolds v. State, 569 NE2d 680 (1991).

${ }^{15}$ See Commonwealth v. Wood, 111 Mass 408 (1873); State v. Goodall, 175 P 857; State v. Prince, 94 A 966.

${ }^{16}$ Cal. Penal Code 597b.
} 
ordinary language sense, but to include any act or omission "whereby unnecessary or unjustified physical pain or suffering is caused or permitted." 17

If taken seriously, provisions of this kind would do a great deal to protect animals from suffering, injury, and premature death. But animal rights, as recognized by state law, are sharply limited, and for two major reasons. ${ }^{18}$ First, enforcement can occur only through public prosecution. If horses and cows are being beaten at a local farm, or if greyhounds are forced to live in small cages, protection will come only if the prosecutor decides to provide it. Of course prosecutors have limited budgets, and animal protection is rarely a high-priority item. The result is that violations of state law occur every day, and there is no way to prevent those violations. The anticruelty prohibitions sharply contrast, in this respect, with most prohibitions protecting human beings, which can be enforced both publicly and privately. For example, the prohibitions on assault and theft can be enforced through criminal prosecutions, brought by public officials, and also by injured citizens, proceeding directly against those who have violated the law.

Second, the anticruelty provisions of state law contain extraordinarily large exceptions. They do not ban hunting, and generally they do not regulate hunting in a way that is designed to protect animals against suffering. They do not apply to the use of animals for medical or scientific purposes. To a large degree, they do not apply to the production and use of animals as food. ${ }^{19}$ The latter exemption is the most important. About ten billion animals are killed for food annually in the United States; indeed, twenty-four million chickens and some 323,000 pigs are slaughtered every day. ${ }^{20}$ The cruel and abusive practices generally involved in contemporary farming are largely unregulated at the state level. ${ }^{21}$ Because the overwhelming majority of animals are produced and used for food, the coverage of anticruelty laws is actually very narrow.

\section{B. Enforcing Existing Rights}

If the suffering of animals matters-and every reasonable person seems to think that it does-we should be greatly troubled by these limitations. The least controversial response would be to narrow the "enforcement gap," by allowing private suits to be brought in cases of cruelty and neglect. Reforms might be adopted with the limited purpose of stopping conduct that is already against the law, so that the law actually means, in practice, what it says on paper. Here, then, we can find a slightly less minimal understanding of animal rights. On this view, representatives of animals should be able to bring private suits to ensure that anticruelty and related laws are actually enforced. If,

\footnotetext{
${ }^{17}$ Cal Penal Code 599b.

${ }^{18}$ I do not discuss here the difficulties introduced by the fact that some statutes allow otherwise unlawful acts if they are "necessary" or "justifiable."

${ }^{19}$ I am putting some complex interpretive questions to one side. The majority of state statutes do not apply to farming, but some of them could, on their face, be so applied.

${ }^{20}$ See David Wolfson, Animals, Agribusiness and the Law: A Modern American Fable, forthcoming in Animal Rights: Law and Policy (Cass R. Sunstein and Martha C. Nussbaum eds. 2003).

${ }^{21}$ See Peter Singer, Animal Liberation 95-158 (revised ed. 2002).
} 
for example, a farm is treating horses cruelly and in violation of legal requirements, a suit could be brought, on behalf of those animals, to bring about compliance with the law.

In a sense, this would be a dramatic proposal, because it might well be understood to mean that animals should be allowed to sue in their own name-and whoever the nominal plaintiff, there would be no question that the suit was being brought to protect animals, not human beings. The very idea might seem absurd. But it is simpler and more conventional than it appears. Of course any animals would be represented by human beings, just like any other litigant who lacks ordinary (human) competence; for example, the interests of children are protected by prosecutors, and also by trustees and guardians in private litigation brought on children's behalf.

It would make sense to build on this idea by allowing suits on behalf of animals too. Why should anyone oppose an effort to promote greater enforcement of existing law, by supplementing the prosecutor's power with private lawsuits? Perhaps the best answer lies in a fear that some or many of those lawsuits would be unjustified, even frivolous. Perhaps animal representatives would bring a flurry of suits, not because of cruelty or neglect or any violation of law, but because of some kind of ideological commitment to improving animal welfare in a way that might go well beyond what the law actually says. If this is a genuine risk, it might make sense to respond, not by banning those lawsuits, but by forcing those who bring frivolous ones to pay the defendants' attorneys fees. Of course there would be issues in deciding on the identity of representatives and choosing the people who would pick them. But we are not yet in especially controversial territory. Many of those who ridicule the idea of animal rights typically believe in anticruelty laws, and they should strongly support efforts to ensure that those laws are actually enforced.

\section{Increased Regulation of Hunting, Science, Farming, and More}

But I think that we should go further. We should focus attention not only on the "enforcement gap," but on the areas where current law offers little or no protection. In short, the law should impose further regulation on hunting, scientific experiments, entertainment, and (above all) farming to ensure against unnecessary animal suffering. It is easy to imagine a set of initiatives that would do a great deal here, and indeed European nations have moved in just this direction. There are many possibilities.

Federal law might, for example, requires scientists to justify experiments on animals by showing, in front of some kind of committee or board, that (a) such experiments are actually necessary or promising, and that (b) the animals involved will be subjected to minimal suffering. Some steps have already been taken in this direction, but it would be reasonable to go much further. If dogs or chimpanzees are going to be used to explore some medical treatment, it should be necessary to ensure that they would be decently fed and housed. Similar controls might be imposed on agriculture. If cows, hens, and pigs are going to be raised for use as food, they should be treated decently in terms of food, space requirements, and overall care. European nations have taken significant steps 
of this sort. ${ }^{22}$ The European Union, for example, has decided to ban the standard bare wire cage for hens, and to require that they be provided with access to a perch and nesting box for laying eggs. ${ }^{23}$ If we focus on suffering, as I believe that we should, it is not necessarily impermissible to kill animals and use them for food; but it is entirely impermissible to be indifferent to their interests while they are alive. So too for other animals in farms, even or perhaps especially if they are being used for the benefit of human beings. If sheep are going to be used to create clothing, their conditions must be conducive to their welfare. We might ban hunting altogether, at least if its sole purpose is human recreation. (Should animals be hunted and killed simply because people enjoy hunting and killing them? The issue might be different if hunting and killing could be justified as having important functions, such as control of populations or protection of human beings against animal violence.)

As a minimal reform step, it would even be possible to imagine a system in which companies disclosed their practices, either voluntarily or as part of a mandate. Companies that protected animals from suffering, and ensured decent conditions, might publicize that fact, and attempt to receive a market boost from the practices.

I believe that steps in this direction would make a great deal of sense. But here things become far more controversial. Why is this? Partly it is because of sheer ignorance, on the part of most people, about what actually happens to animals in (for example) farming and scientific experimentation. I am confident that much greater regulation would be actively sought if current practices were widely known. Partly the controversy is a product of the political power of the relevant interests, which intensely resist regulation. But some legitimate questions might be raised about some of these regulatory strategies, for one simple reason: The legitimate interests of animals and the legitimate interests of human beings are in conflict in some of these areas. Here as elsewhere, additional regulation would be costly and burdensome. It is possible to fear that regulation of scientific experiments on animals would lead to less scientific experiments on animals - and hence to less in the way of scientific and medical progress. If farms are regulated, the price of meat will increase, and people will be able to eat less meat. Hence it is necessary to weigh the gain to animal welfare against the harms to human beings. If the health of human beings could be seriously compromised by regulation of experiments on animals and farming, there is reason to engage in some balancing before supporting that regulation.

\footnotetext{
${ }^{22}$ Under its common agricultural policy, the European Union adopted the European Convention for the Protection of Animals Kept for Farming Purposes on Nov. 17, 1978. European Convention for the Protection of Animals Kept for Farming Purposes, 1978 O.J. (L 323)12. The Convention applies to the "keeping, care and housing of animals, and in particular to animals in modern intensive stock-farming systems." In Articles 3 to 7, the Convention provides detailed principles of animal welfare. The Convention was amended and strengthened on December 31, 1992. Protocol of Amendment to the European Convention for the Protection of Animals Kept for Farming Purposes, 1992 O.J. (L 395) 22. Under the Convention, the EU has established specific regulations for such activities as the keeping of laying hens. Council Directive 1999/74/EC Laying Down Minimum Standards for the Protection of Laying Hens, O.J. (L 203) 53. Members of the European Union have enacted implementing legislation. The United Kingdom Department for Environmental, Food and Rural Affairs (DEFRA) has been active. See www.defra.gov.uk.

${ }^{23}$ See Peter Singer, Animal Liberation x (revised edition 2002).
} 
Any such balancing must depend, on part, on values - on how much weight we should assign to the relevant interests. At the very least, I suggest that suffering and harm to animals should count, and that any measures that impose suffering and harm should be convincingly justified. If animals are being made to suffer to produce cosmetics and hair dyes, the justification seems weak. To make a sensible assessment, it would be helpful to know a great deal about the facts, not only about values. One of the most important disputes, in the domain of scientific experimentation, is whether and to what extent the relevant experiments really hold out a great deal of promise for medical progress. If we are speaking of perfumes, the claim for imposing suffering on animals is ludicrously weak. But if scientists are able to develop treatments for AIDS and cancer, the claim is much stronger.

Now some animal rights advocates might urge that even if the gains from a certain practice are very large, experiments are not justified. We do not, after all, allow scientists to experiment on human beings, even human beings with serious disabilities, when and because medical advances would be significant. But there are many complications here. Some utilitarians would not find it easy to explain why we impose absolute barriers in cases of this kind. But I believe that it is excessive to ban experiments that impose a degree of suffering on rats or mice if the consequence of those experiments would to produce significant medical advances for human beings (and ultimately nonhuman animals as well).

\section{Eliminating Current Practices, Including Meat-Eating}

Now turn to some quite radical suggestions. Suppose that we continue to believe that animal suffering is the problem that should concern us, and that we want to use the law to promote animal welfare. We might conclude that certain practices cannot be defended and should not be allowed to continue, if, in practice, mere regulation will inevitably be insufficient - and if, in practice, mere regulation will ensure that the level of animal suffering will remain very high. To make such an argument convincing, it would be helpful, whether or not necessary, to argue not only that the harms to animals are serious, but also that the benefits, to human beings, of the relevant practices are simply too small to justify the continuation of those practices. Many people who urge radical steps-who think, for example, that people should not eat meat-do so because they believe that without such steps, the level of animal suffering will be unacceptably severe.

To evaluate an argument of this kind, there is no choice but to go area by area. Consider greyhound racing. Greyhounds live in miserable conditions and many of them are put to death after their racing careers are over. I believe that if possible, the preferred step should be to use the law to ensure that greyhounds are given decent lives-and to hope that the racing industry will comply with law that has that goal. But if it proves impractical for law to ensure that greyhounds live minimally decent lives, ${ }^{24}$ I believe that that greyhound racing should be abolished. The entertainment gain, for some people,

\footnotetext{
${ }^{24}$ This might be because it is not feasible to provide decent care for greyhounds and to run a profitable racing business.
} 
cannot justify significant suffering. Of course the largest issue involves eating meat. I believe that that meat-eating would be acceptable if decent treatment is given to the animals used for food. Killing animals, whether or not troublesome, is far less troublesome than suffering. But if, as a practical matter, animals used for food are almost inevitably going to endure terrible suffering, then there is a good argument that people should not eat meat to the extent that a refusal to eat meat will reduce that suffering. Of course a legal ban on meat-eating would be extremely radical, and like prohibition, it would undoubtedly create black markets and have a set of bad, and huge, side-effects. But the principle seems clear: People should be much less inclined to eat meat if their refusal to do so would prevent significant suffering.

There is an objection, utilitarian in spirit, to steps of this kind. If people do not eat meat, or if they take other steps to prevent animals from suffering, the inevitable result will be to ensure that fewer animals exist. Perhaps it is objectionable to protect animals through measures that reduce the total number of animals. Perhaps it is better for animals to have lives, even difficult ones, than not to have lives. But I think that this objection is weak. We should increase the likelihood that animals will have good lives-we should not try to ensure that there are as many animals as possible.

My argument - that we should consider refraining from certain practices if this is the only feasible way to avoid widespread suffering-raises a host of questions. As before, the argument raises issues of fact. Shouldn't it be possible to reduce the level of suffering in scientific experiments by, for example, requiring animals to be adequately sheltered and fed? Why couldn't farms generally give their animals decent lives, as many farms now do? It would also be valuable to ask some factual questions. If vegetarianism were widespread, would human health be undermined (as many contend) or improved (as many also contend)? After the factual questions are resolved, disputes will remain about the weight to be given to the various interests. My suggestion is that on a reasonable reading of the facts, many practices will have to yield.

\section{E. The Question of Animal Autonomy}

Of course some people might go further. They might focus not only, and perhaps not mostly, on the relief of suffering. On one view, animals have rights in the sense that they should not be subject to human use and control. Notice that this is not a Benthaminspired point about the prevention and relief of suffering. It is instead a suggestion that animals deserve to have a kind of autonomy. And the suggestion goes well beyond the view, which seems to me correct, that animals should be seen as ends rather than solely as means. Many people who use chimpanzees in entertainment or zoos, or who use horses for racing, do not consider the relevant animals to be mere means to human ends. They agree that animals have intrinsic as well as instrumental value. But those who think that animals should not be subject to human control tend to object to all of these uses. They want all or most animals to be able to make their own choices, free from human control.

This claim raises many questions, and in the end it seems to me extreme and unconvincing, mostly because it neglects the possibility that animals will have bad lives 
under natural conditions, and much better lives under a degree of human control. The most obvious point is that it is not clear whether and how this position might be applied to companion animals. Dogs and cats, among others, have been bred specifically for human companionship, and many of them would not fare well on their own. Perhaps those who believe in animal autonomy would accept the idea that people can substantially control animals who have been bred to live with them. Perhaps the autonomy argument would apply only to wild animals -- forbidding human beings from hunting, trapping, and confining them.

But what if certain practices, such as confinement in zoos, science labs, and other facilities, can be undertaken in a way that ensures good lives for the relevant animals? What if some animals, including dolphins and elephants, would do very well under human control? Nature can be very cruel, after all, and many animals will live longer lives with human beings than in the wild. Of course longer is not necessarily better. But good zoos have breeding programs that protect endangered species, give good care to animals, and serve an important function (for nonhuman animals and human beings alike) in educating people about the nature and worth of animals. Indeed we could imagine that many lions, elephants, giraffes, and dolphins could, in fact, have better lives with human assistance, even if confined, than in their own habitats. If this is so, it is not simple to see what sort of response might be made by those who believe in animal autonomy. Perhaps autonomy advocates disagree on the facts, not on the theoretical issue, and think it highly unlikely, in most cases, that wild animals can have decent lives under human control. I do not believe that they are correct on the facts. In any case the claim for animal autonomy must, in the end, depend on an assessment of what will give animals good lives.

\section{Are Animals Property?}

I have not yet explored the ongoing debate over the status of animals as "property." This is one of the most vigorous debates of all. ${ }^{25}$ What underlies this debate?

There is no single answer. Those who insist that animals should not be seen as property might be making a simple and modest claim: Human beings should not be able to treat animals however they wish. Their starting point seems to be this: If you are property, you are, in law and in effect, a slave, wholly subject to the will of your owner. Mere property cannot have rights of any kind. A table, a chair, or a stereo can be treated as the owner likes; it can be broken or sold or replaced at the owner's whim. For animals, it might be thought, the status of property is devastating to actual protection against cruelty and abuse.

On this view, a central goal of the modern animal rights movement -- eliminating the idea that animals are property -- can be taken in a modest way, as an effort to remove a legal status that inevitably promotes suffering. But the goal can be taken far more ambitiously, as an effort to say that animals should have rights of self-determination, or a certain kind of autonomy. Hence some people urge that certain animals, at least, are "persons," not property, and that they should have many of the legal rights that human

\footnotetext{
${ }^{25}$ See Steven Wise, Ratting the Cage (2000).
} 
beings have. ${ }^{26}$ Of course this does not mean that those animals can vote or run for office. Their status would be akin to that of children-a status commensurate with their capacities. What that status is, particularly, remains to be spelled out. But at a minimum, it would seem to entail protection against torture, battery, and even confinement (except for purposes of human self-defense).

There is, however, a puzzle here. What does it mean to say that animals are property and can be "owned"? As we have seen, animals, even if owned, cannot be treated however the owner wishes; the law already forbids cruelty and neglect. Ownership is just a label, connoting a certain set of rights and perhaps duties, and without knowing a lot more, we cannot identify those rights and duties. A state could dramatically increase enforcement of existing bans on cruelty and neglect without turning animals into persons, or making them into something other than property. A state could do a great deal to prevent animal suffering, without banning the ownership of animals. We could even grant animals a right to bring suit without insisting that animals are in some general sense "persons," or that they are not property. A state could certainly confer rights on a pristine area, or a painting, and allow people to bring suit on its behalf, without therefore saying that that area and that painting may not be owned. In the context of children's rights, the assertion that "children are not property" is universally accepted, but appears not to have added anything to debates over how parents may treat children.

What, then, are the real stakes in the debate over whether animals are "property"? Perhaps it is thought necessary to destroy the idea of ownership in order to make, simply and all at once, a statement that the interests of animals count, and have weight independent of the interests of human beings. Rhetoric can matter, and in my view, the idea of "property" does fit very poorly with how people should think, on reflection, about other living creatures. On this view, the debate over whether animals are property is really a debate over the more specific issues discussed above. If getting rid of the idea that animals are property is helpful in reducing suffering, then we should get rid of the idea that animals are property.

\section{Which Animals Have Rights?}

There is an large question in the background. People do not see all animals in the same way. They might agree that human beings should protect the interests of dogs, cats, horses, and dolphins; they are unlikely to think the same about ants and mosquitoes and cockroaches; rats and mice and squirrels seem to be an intermediate case. It is often objected, to those who believe in animal rights, that their position would lead to truly ludicrous conclusions-to the (ridiculous?) suggestion that people cannot kill ants or mosquitoes, or rid their houses of rats and cockroaches.

There are two ways to answer this objection. One way, of special appeal to those who stress autonomy, would inquire into the cognitive capacities of the particular animals involved. We would draw the line by seeing how well the animals in question think. ${ }^{27}$

\footnotetext{
${ }^{26} \mathrm{Id}$.

${ }^{27}$ See Steven Wise, Drawing the Line (2002).
} 
But this seems to me misdirected; Bentham was right to place the emphasis on whether and to what extent the animal in question is capable of suffering. If rats are able to suffer-and no one really doubts that they are-then their interests are relevant to the question how, and perhaps even whether, they can be expelled from houses. ${ }^{28}$ At the very least, people should kill rats in a way that minimizes suffering. And if possible, people should try to expel rats in a way that does not harm them at all.

These claims need not be taken as radical or extreme; many people already take steps in just this direction. If we are getting rid of rats, we do so in a way that reduces, rather than maximizes, their distress. On this view, if ants and mosquitoes have no claim to human concern - if they can be killed at our whim-it is because they suffer little or not at all. Here we have some empirical questions about the capacities of creatures of various sorts. And we should certainly be willing to engage in a degree of balancing. If human beings are at risk of illness and disease from mosquitoes and rats, they have a strong justification, perhaps even one of self-defense, for eliminating or relocating them.

\section{Conclusion}

Every reasonable person believes in animal rights. Even the sharpest critics of animal rights support the anticruelty laws. I have suggested that the simple moral judgment behind these laws is that animal suffering matters, and that this judgment supports a significant amount of reform. Most modestly, private suits should be permitted to prevent illegal cruelty and neglect. There is no good reason to give public officials a monopoly on enforcement; that monopoly is a recipe for continued illegality. Less modestly, anticruelty laws should be extended to areas that are now exempt from them, including scientific experiments and farming. There is no good reason to permit the level of suffering that is now being experienced by millions, even billions of living creatures.

I have also raised doubts about the radical idea that animals deserve to have "autonomy," understood as a right to be free from human control and use. In my view, the real questions involves animal welfare and suffering, and human control and use may be compatible with decent lives for animals. But the emphasis on suffering, and on decent lives, itself has significant implications. Of course it is appropriate to consider human interests in the balance, and sometimes our interests will outweigh those of other animals. The problem is that most of the time, the interests of animals are not counted at all-and that once they are counted, many of our practices cannot possibly be justified. I believe that in the long-run, our willingness to subject animals to unjustified suffering will be seem a form of unconscionable barbarity - not the same as, but in many ways morally akin to, slavery and the mass extermination of human beings.

\footnotetext{
${ }^{28}$ If an animal carries disease, the issue is different; in that case expulsion can be seen as a matter of selfdefense.
} 
Readers with comments should address them to:

Cass R. Sunstein

University of Chicago Law School

1111 East 60th Street

Chicago, IL 60637

csunstei@midway.uchicago.edu 


\section{University of Chicago Law School}

\section{Public Law and Legal Theory Working Paper Series}

1. Cass R. Sunstein and Edna Ullmann-Margalit, Second-Order Decisions (November 1999; Ethics, v. 110, no. 1).

2. Joseph Isenbergh, Impeachment and Presidential Immunity from Judicial Process (November 1999; forthcoming Yale Law and Policy Review v.18 \#1).

3. Cass R. Sunstein, Is the Clean Air Act Unconstitutional? (August 1999; Michigan Law Review \#3).

4. Elizabeth Garrett, The Law and Economics of "Informed Voter" Ballot Notations (November 1999, University of Virginia Law Review, v. 85).

5. David A. Strauss, Do Constitutional Amendments Matter? (November 1999)

6. Cass R. Sunstein, Standing for Animals (November 1999)

7. Cass R. Sunstein, Culture and Government Money: A Guide for the Perplexed (April 2000).

8. Emily Buss, Without Peers? The Blind Spot in the Debate over How to Allocate Educational Control between Parent and State (April 2000).

9. David A. Strauss, Common Law, Common Ground, and Jefferson's Principle (June 2000).

10. Curtis A. Bradley and Jack L. Goldsmith, Treaties, Human Rights, and Conditional Consent (May 2000; Pennsylvania Law Review v. 149).

11. Mary Ann Case, Lessons for the Future of Affirmative Action from the Past of the Religion Clauses? (May 2001, Supreme Court Review, 2000)

12. Cass R. Sunstein, Social and Economic Rights? Lessons from South Africa (May, 2000).

13. Jill Elaine Hasday, Parenthood Divided: A Legal History of the Bifurcated Law of Parental Relations

14. Elizabeth Garrett, Institutional Lessons from the 2000 Presidential Election (May 2001).

15. Richard A. Epstein, The Allocation of the Commons: Parking and Stopping on the Commons (August 2001).

16. Jack Goldsmith, The Internet and the Legitimacy of Remote Cross-Border Searches (October 2001).

17. Adrian Vermeule, Does Commerce Clause Review Have Perverse Effects? (October 2001).

18. Cass R. Sunstein, Of Artificial Intelligence and Legal Reasoning (November 2001).

19. Elizabeth Garrett, The Future of Campaign Finance Reform Laws in the Courts and in Congress, The William J. Brennan Lecture in Constitutional Law (December 2001).

20. Julie Roin, Taxation without Coordination (March 2002).

21. Geoffrey R. Stone, Above the Law: Research Methods, Ethics, and the Law of Privilege (March 2002; forthcoming J. Sociological Methodology 2002). 
22. Cass R. Sunstein, Is There a Constitutional Right to Clone? (March 2002).

23. Emily Buss, Parental Rights (May 2002, forthcoming Virginia Law Review).

24. David A. Strauss, Must Like Cases Be Treated Alike? (May 2002).

25. David A. Strauss, The Common Law Genius of the Warren Court (May 2002).

26. Jack Goldsmith and Ryan Goodman, U.S. Civil Litigation and International Terrorism (June 2002).

27. Jack Goldsmith and Cass R. Sunstein, Military Tribunals and Legal Culture: What a Difference Sixty Years Makes (June 2002).

28. Cass R. Sunstein and Adrian Vermeule, Interpretation and Institutions (July 2002).

29. Elizabeth Garrett, Is the Party Over? The Court and the Political Process (August 2002).

30. Cass R. Sunstein, The Rights of Animals: A Very Short Primer (August 2002). 